\title{
Technological and nutritional properties of ostrich, emu, and rhea meat quality
}

\author{
Olaf K. Horbańczuk, Agnieszka Wierzbicka \\ Faculty of Human Nutrition and Consumer Sciences, \\ Warsaw University of Life Sciences, 02-776 Warsaw, Poland \\ ollafson@onet.pl
}

Received: August 4, 2016

Accepted: September 7, 2016

\begin{abstract}
In recent years a growing demand for ratite meat, including ostrich, emu, and rhea has been observed all over the world. However, consumers as well as the meat industry still have limited and scattered knowledge about this type of meat, especially in the case of emu and rhea. Thus, the aim of the present review is to provide information on technological and nutritional properties of ostrich, emu, and rhea meat, including carcass composition and yields, physicochemical characteristics, and nutritive value. Carcass yields and composition among ratites are comparable, with the exception of higher content of fat in emu. Ostrich, emu, and rhea meat is darker than beef and ratite meat acidification is closer to beef than to poultry. Ratite meat can be recognised as a dietetic product mainly because of its low level of fat, high content of polyunsaturated fatty acids (PUFA), favourable n6/n3 ratio, and high iron content in comparison with beef and chicken meat. Ratite meat is also rich in selenium, copper, vitamin B, and biologically active peptides such as creatine (emu) and anserine (ostrich), and has low content of sodium (ostrich). The abundance of bioactive compounds e.g. PUFA, makes ratite meat highly susceptible to oxidation and requires research concerning elaboration of innovative, intelligent packaging system for protection of nutritional and technological properties of this meat.
\end{abstract}

Keywords: emu, ostrich, rhea, meat, quality.

\section{Introduction}

Over the recent years growing interest in ratite farming and breeding, including ostriches, emu, and rhea, has been observed worldwide $(4,5,7,11,22,32$, $42,44)$ as a new agricultural activity $(8,21)$. For example, the South African ostrich meat industry has grown considerably over the past years and export constitutes approximately $90 \%$ of global ostrich meat production in the world (24). Apart from South Africa, ostrich farming is developing in China, Brazil, Iran, and in several European countries, including Poland (23), which is now one of the largest producers of ostrich meat in Europe (6).

Emu is the second largest bird in the world and is the largest avian species native to Australia, where commercial emu farming has been successful since the 1980s $(31,34)$. In the United States more than one million emus are raised as a specialty livestock for meat, oil, and leather (55). According to Navenna et al. $(33,34)$, emu farming in India has presently expanded to around 3000 farms in more than in 15 states, accounting for 2.5 million birds.

In turn, rhea (nandu) is a flightless bird native to South America, inhabiting extensive areas in Argentina, Bolivia, Paraguay, Southern Brazil, and Uruguay $(12,13,47)$. Currently rhea farming is rapidly growing in Uruguay to provide the local and the international market with meat, leather, feathers, and oil (56).

One of the important aspects of worldwide growing interest in ratite meat several years ago was the outbreak of BSE and foot-and-mouth disease in UK (6). The consumption of beef at that time decreased and consumers started to look for red meat from alternative species, such as ratite. Moreover, in the developed meat markets where supply frequently exceeds demand, attention was given to flightless birds (ostriches, emus, rheas) as a "new" alternative red meat due to a favourable fatty acid profile (n6/n3 ratio), low level of fat, and high content of minerals (iron) as well as vitamin $B$. It should be stressed that recently both the 
consumer and the industry pay special attention to the quality of products, including technological aspects, and search for safe, tasty, and healthy food, known as functional food, which is characterised by high nutritive value. However, their knowledge about ratite meat, especially in the case of emu and rhea meat, is still limited, scattered, and sparse (1, 12, 37, 38, 42). Scientific information on yields, ratite meat quality, and nutritional value is required if industry and producers are to promote ostrich, emu, and rhea meat in both local and international markets.

Therefore, the present review attempts to provide information on the technological and nutritional properties, including carcass composition and yields, physicochemical characteristics as well as nutritive value of ostrich, emu, and rhea meat.

\section{Carcass characteristics}

The data concerning live weight, yield of carcass, and carcass composition are presented in Table 1 . Ostriches are usually slaughtered at the age of 10-12 months, achieving 90-95 $\mathrm{kg}$ of live body weight. Ostrich carcass weight is ca. $58 \%-59 \%$ of live weight and lean meat comprises about $62.5 \%$ of the carcass, which is comparable with beef and chicken meat. Fat is $9.2 \%$ and bones $26 \%$ of the carcass. Interestingly, ostrich skin, which is a very valuable product on the world market, weighs $6.7 \mathrm{~kg}$ and comprises $7 \%$ of live weight, which is higher compared to rhea $(4.58 \%)$ and emu skin (1.84\%).

Emus are usually slaughtered at the age of 14 months, with a live weight around $40 \mathrm{~kg}$ and dressing percentage of $52.6 \%$ excluding fat, skin, and neck (49).
The meat yield of around $32 \%$ of emu live weight is lower than in ostriches and rheas (Table 1). It should be underlined that apart from meat the other very important product of great economic significance in emu is fat $(28,48)$, which is characterised by antiinflammatory potential and has been used in treatment of various ailments for decades (19). Emu yields an average $11 \mathrm{~kg}$ of fat, which is $27 \%$ of total live weight of the bird (34), whereas values of $5.2 \%$ and $6.6 \%$ were reported for ostriches (30) and rheas (50), respectively. Emus have significantly lower percentage of bones $(10.4 \%)$ as compared to ostriches $(15.3 \%)$ and rheas (13\%).

Rheas are slaughtered at the age of 12 months when the birds achieve ca $25 \mathrm{~kg}$. The dressing percentage of rheas is generally comparable to ostrich and higher than in emu (without fat). Likewise, lean meat, fat, and bone on a body and carcass weight basis are similar to ostriches (50). As regards edible organs, the heart comprises $1 \%$ of the live weight in all ratites, whereas the liver weight varies from $1.3 \%$ (emu) to $2.2 \%$ (rhea) of body weight.

\section{Chemical and physical composition}

Physicochemical and proximate composition of ostrich, emu, and rhea is shown in Table 2. Overall, the protein and ash content was similar among ratite birds (16). The same tendency was observed in the case of fat content, although ostrich meat was the leanest as compared to emu and rhea (Table 2). It should be noted that ratite meat has a very low fat content compared with pork or beef (40), which is especially important for consumers committed to weight control (37).

Table 1. Carcass yield and carcass composition of ostrich, emu, and rhea

\begin{tabular}{|c|c|c|c|c|c|c|}
\hline \multirow[b]{2}{*}{ Component } & \multicolumn{2}{|c|}{ Ostrich $^{1}$} & \multicolumn{2}{|c|}{$\mathrm{Emu}^{2}$} & \multicolumn{2}{|c|}{ Rhea $^{3}$} \\
\hline & Weight (kg) & $\begin{array}{c}\text { Live weight } \\
(\%)\end{array}$ & Weight (kg) & $\begin{array}{c}\text { Live weight } \\
(\%)\end{array}$ & Weight (kg) & $\begin{array}{c}\text { Live weight } \\
(\%)\end{array}$ \\
\hline Live weight & 95.54 & 100 & 41.00 & 100 & 25.1 & 100 \\
\hline Carcass weight & 55.91 & - & 19.58 & - & 14.97 & - \\
\hline Dressing percentage & - & 58.59 & - & $47.77^{*}$ & - & 59.6 \\
\hline Meat & 34.11 & 35.70 & 13.00 & 31.70 & 9.97 & 38.8 \\
\hline Fat & 5.03 & 5.20 & 11.06 & 26.99 & 1.64 & 6.6 \\
\hline $\begin{array}{l}\text { Bones } \\
\text { Feathers }\end{array}$ & $\begin{array}{l}14.61 \\
1.74\end{array}$ & $\begin{array}{l}15.30 \\
1.85\end{array}$ & $\begin{array}{l}4.27 \\
0.45\end{array}$ & $\begin{array}{l}10.42 \\
1.09\end{array}$ & $\begin{array}{l}3.26 \\
0.44\end{array}$ & $\begin{array}{l}13.0 \\
1.76\end{array}$ \\
\hline Blood & 2.98 & 3.11 & 2.00 & 4.87 & 1.25 & 4.94 \\
\hline Wings & 0.74 & 0.78 & 0.11 & 0.27 & 0.63 & 3.18 \\
\hline Feet & 2.51 & 2.64 & 1.54 & 3.76 & 0.81 & 3.89 \\
\hline Tail & 0.36 & 0.38 & 0.17 & 0.42 & 0.04 & 0.14 \\
\hline Head & 0.78 & 0.82 & 0.33 & 0.80 & 0.41 & 1.62 \\
\hline Skin & 6.71 & 7.04 & 0.77 & 1.87 & 0.78 & 4.58 \\
\hline Heart & 0.94 & 0.99 & 0.37 & 0.91 & 0.28 & 1.09 \\
\hline Lungs and trachea & 1.29 & 1.36 & 0.30 & 0.73 & 0.3 & 1.18 \\
\hline Empty gizzard & 2.15 & 2.26 & 0.54 & 1.34 & 0.52 & 2.08 \\
\hline Liver & 1.42 & 1.49 & 0.54 & 1.34 & 0.57 & 2.26 \\
\hline Viscera & 8.29 & 8.68 & 0.83 & 2.03 & 2.35 & 9.82 \\
\hline
\end{tabular}

${ }^{1}$ Morris et al. (30), ${ }^{2}$ Naveena et al. (34), ${ }^{3}$ Sales et al. (50), ${ }^{*}$ excluding fat 
Table 2. Physicochemical and proximate composition of ostrich, emu, and rhea meat

\begin{tabular}{llll}
\hline & Ostrich $^{1}$ & $\mathrm{Emu}^{2}$ & Rhea $^{3}$ \\
\hline Dry matter (\%) & 76.2 & 74.8 & 74.1 \\
\hline Protein (\%) & 21.6 & 22.3 & 22.5 \\
\hline Fat (\%) & 1.1 & 1.8 & 1.6 \\
\hline Ash (\%) & 1.1 & 1.21 & 1.52 \\
\hline $\mathrm{pH}_{45}$ & 6.17 & 5.5 & $6.2^{5}$ \\
\hline $\mathrm{pH}_{24}$ & 6.12 & 5.69 & $5.99^{5}$ \\
\hline $\mathrm{L}^{*}$ & 28.6 & $344^{4}$ & $16.5^{6}$ \\
\hline $\mathrm{a}^{*}$ & 17.2 & $14.3^{4}$ & $8.1^{6}$ \\
\hline $\mathrm{b}^{*}$ & 10.4 & $10^{4}$ & - \\
\hline WHC $(\%)$ & 23.0 & $15.3-23.3^{4}$ & $41.9^{6}$ \\
\hline Cooking loss (\%) & 37.4 & - & - \\
\hline WB (N/cm $\left.{ }^{2}\right)$ & 33.5 & 29.5 & \\
\hline
\end{tabular}

${ }^{1}$ Polawska et al. (39), ${ }^{2}$ Naveena et al. (34), ${ }^{3}$ Romanelli et al. (46), ${ }^{4}$ Berge et al. (2), ${ }^{5}$ Sales et al. (49), ${ }^{6}$ Filgueras et al. (11)

As regards the physical characteristics of meat, colour is the first feature inspected by the consumer in selection of any meat (38). Ratite meat is classified as a newly marketed dark red meat which is darker than beef. It can be explained by a high pigment content ranging between 3.2 and $5 \mathrm{mg}$ of $\mathrm{Fe} / 100 \mathrm{~g}$ versus ca. $2 \mathrm{mg}$ of $\mathrm{Fe} / 100 \mathrm{~g}$ in beef $(32,40,44,45)$. Interesting research for meat physical quality including colour and $\mathrm{pH}$ on different ostrich genotype South African Black (Black), Zimbabwean Blue (Blue), and their hybrids was carried out by Hoffman et al. (18). In their study the meat colour of the pure Blue genotype was darker than other genotypes because of the high $\mathrm{pH}_{24}$. The lightness $\left(\mathrm{L}^{*}\right)$ value for 10 different muscles from three subspecies of ostrich varied from 27.4 to 34.4 , whereas $\mathrm{a}^{*}$ value ranged from 10.7 to 17.1 and $\mathrm{b}^{*}$ from 6.0 to 9.3. As compared to other ratite species, ostrich meat is darker (Table 2).

Meat quality is heavily influenced by the rate of $\mathrm{pH}$ decline in the muscles after slaughter and by the ultimate $\mathrm{pH}$. In the study by Hoffman et al. (18) when comparing the pure Blue to pure Black genotype, the data for the former showed that $70 \%$ of the muscles had a higher $\mathrm{pH}_{24}$, and $50 \%$ of the muscles were redder. Furthermore, pure Blue ostriches are larger $(\mathrm{P}<0.05)$ than the pure Black ostriches and exhibit "skittishness" (nervousness) which makes this subspecies more difficult to manage and handle during the ante-mortem stages. Difficulties during pre-slaughter handling cause animals to stress leading to depleted glycogen in the muscles and high post-mortem $\mathrm{pH}_{24}$ of the meat. Hoffman et al. (15) reported that an ultimate $\mathrm{pH}$ of 5.91 was achieved in ostrich meat within 2-4 $\mathrm{h}$ after slaughter followed by an increase in $\mathrm{pH}$ during storage up to $24 \mathrm{~h}$. In studies by Poławska et al. (39) and Chang et al. (3), the $\mathrm{pH}$ was similar (6.1). Sales et al. (51) reported that similarly to ostrich and rhea meat
(Table 2), emu meat is also characterised by relatively high final $\mathrm{pH}$ values (6.0) that cause dark colour, high water-holding capacity, and limited shelf life of meat, and are normally associated with pre-slaughtered stress. In the recent study conducted on emus by Naveena et al. (34), the mean muscle $\mathrm{pH}$ value of 5.5 and an ultimate $\mathrm{pH}$ of 5.69 was reported. In turn, Berge et al. (2) established the final $\mathrm{pH}$ values of ca. 5.6, but the emus were rested for a period of two weeks in the vicinity of the abattoir. Based on the report on ostrich by Paleari et al (35) it can be concluded that ratite acidification is closer to beef (loin $\mathrm{pH}-5.8$ ) than to poultry meat (thigh $\mathrm{pH}-6.3$ ).

Such technological meat parameters as cooking loss, water holding capacity (WHC), and WarnerBratzler shear-force (WB) are generally comparable in ratite meats (Table 2). Hoffman et al. (18) demonstrated that in pure Blue genotype the percentage cooking loss and drip loss was the lowest. Interestingly, Poławska et al. (39), who investigated the effect of dietary linseed and rapeseed supplements on the physicochemical properties of ostrich meat, found that although rapeseed did not affect the physical properties of meat, linseed led to a decrease in cooking loss.

\section{Nutritional characteristics of ostrich, emu, and rhea meat}

Cholesterol. Cholesterol content in ratite meat is generally low, especially in ostrich meat, and is lower as compared to beef and chicken meat (Table 3). Its values reported for raw ratite meat varied from 53$54 \mathrm{mg} / 100 \mathrm{~g}$ in ostrich, $58 \mathrm{mg} / 100 \mathrm{~g}$ in emu, and to $56-$ $81 \mathrm{mg} / 100 \mathrm{~g}$ in rhea. Cholesterol is mainly situated as a structural component in cell membranes. There is substantive evidence that cholesterol is stored in blood 
vessels of persons suffering from arteriosclerosis, potentiating heart infarction. Cholesterol-phobia is thus a common phenomenon in developed countries (37).

Ostrich meat has lower calorific value of $390 \mathrm{~kJ} / 100 \mathrm{~g}$ when compared to emu and rhea (Table 3), and especially to beef $(517 \mathrm{~kJ} / 100 \mathrm{~g})$, which makes it a valuable lean meat. As recommended by the WHO (58), only $30 \%$ of daily energy intake should come from fat, so ratite meat can be a good source of protein with low calorific value.

Fatty acid composition. Fatty acid profile of ostrich, emu, and rhea meat was shown in Table 3. Ratite meat has a very good fatty acid profile (52) in comparison with beef and chicken (Table 3). For example, the PUFA content in ratites clearly achieves higher levels compared to chicken meat $-19 \%$ and beef $-4.8 \%$ (59). Among ratite species the highest concentration of PUFA (39.1\%) in total FA is found in rhea meat. However, the total amounts of $n 3$, the most desired FA in human diet, was reported in ostrich meat $>8 \%$, which is doubled compared to emu $(3 \%)$ and rhea meat $(4.5 \%)$, and much higher than in chicken meat $(2.4 \%)$ and beef $(0.6 \%)$. The same tendency was recorded in the case of linolenic acid (18:3). DHA (22:6) and EPA (20:5) n3 PUFA in ostrich are also found to be higher than in emu and rhea meat, as well as in beef and chicken meat (Table 3).

Long chain n3 PUFA are recognised as essential constituents for normal growth and development in human. The n3 fatty acids such as DHA can also contribute to the development of infant brain and liver $(38,41)$. It should also be underlined that ostrich meat is characterised by the most favourable $n 6 / n 3$ ratio as compared to other ratites as well as beef and chicken meat (Table 3). As regards n6/n3 ratio it was also observed that dietary fish oil and linseed had a positive effect on the fatty acid profile of the ostrich muscle due to increased levels of the long chain polyunsaturated fatty acids like EPA and DHA $(17,40,43)$. Moreover, Filgueras et al. (11) demonstrated that in rhea the amount of n3 PUFA was also influenced by muscles, e.g. the ratio $\mathrm{n} 6 / \mathrm{n} 3$ was 1.2 times lower in the $m$. gastrocnemius than in the $m$. iliofibularis.

Especially in the case of ostrich meat, the favourable ratio of $n 6 / n 3$ may play a key role in wide promotion of ratite meat due to the fact that Western diets are deficient in $\mathrm{n} 3$ fatty acids and have excessive amounts of $n 6$ fatty acids. Simopoulos (54) emphasises that the ratio $\mathrm{n} 6 / \mathrm{n} 3$ in Western diets is $15 / 1-16 / 1$ and should be below 4:1 according to the World Health Organisation (58). A high $\mathrm{n} 6 / \mathrm{n} 3$ ratio, as is found in today's Western diets, leads to many diseases such as cardiovascular disease, cancer, osteoporosis, inflammatory and autoimmune diseases, whereas increased levels of omega-3 PUFA exert suppressive effects (53). A lower ratio of n6/n3 fatty acids is more desirable in reducing the risk of many chronic diseases of high prevalence in human (54).

Minerals and vitamins. Ratite meat is considered as an important source of minerals, especially iron, copper, and selenium (Table 4). For example, the concentration of iron in ostrich and emu meat exceeded $4 \mathrm{mg} / 100 \mathrm{~g}$ compared to $3.2 \mathrm{mg} / 100 \mathrm{~g}$ for rhea meat. These values are much higher than those generally reported for chicken meat $(0.4-0.6 \mathrm{mg} / 100 \mathrm{~g})$ and also higher than beef (1.7-2 mg/100 g). Moreover, Walter et al. (57) examined the iron content of ground ostrich meat versus ground beef and found that the former had significantly higher iron content than the latter. It should be noted that iron deficiency is the most prevalent nutritional disorder in the world, particularly in developing countries (8).

Table 3. Comparison of cholesterol and fatty acids profile of ostrich, emu, and rhea meat

\begin{tabular}{|c|c|c|c|c|c|}
\hline & Ostrich $^{1}$ & $E m u^{2}$ & Rhea $^{3}$ & Beef $^{4}$ & Chicken $^{5}$ \\
\hline Cholesterol (mg/100g) & $53-54$ & 58 & $56-81$ & 67 & $58-74$ \\
\hline Calories kcal/100g & 92 & 105 & $113-127$ & 123 & 121 \\
\hline Energy $(\mathrm{kJ} / 100 \mathrm{~g})$ & 390 & 439 & $471-531$ & 517 & 508 \\
\hline $14: 0$ & 0.75 & 0.40 & 0.43 & 2.98 & 0.73 \\
\hline $16: 0$ & 21.73 & 22.43 & 19.35 & 27.9 & 23.42 \\
\hline $18: 0$ & 14.08 & 10.42 & 13.78 & 14.0 & 10.36 \\
\hline Total SFA & 39.73 & 33.30 & 34.44 & 44.88 & 33.28 \\
\hline $16: 1$ & 3.51 & 3.49 & 2.39 & 3.45 & 4.27 \\
\hline $18: 1$ & 21.15 & 37.63 & 20.28 & 36.03 & 37.52 \\
\hline Total MUFA & 27.27 & 41.95 & 26.09 & 39.48 & 42.39 \\
\hline $18: 2 \mathrm{n} 6$ & 18.06 & 15.19 & 22.01 & 3.07 & 12.78 \\
\hline $18: 3 \mathrm{n} 3$ & 5.76 & 1.31 & 2.14 & 0.29 & 0.84 \\
\hline $20: 4$ n6 & 6.15 & 5.37 & 10.46 & 0.63 & 2.55 \\
\hline $20: 5 \mathrm{n} 3$ & 1.21 & 0.41 & 0.90 & 0.1 & 0.47 \\
\hline $22: 5 \mathrm{n} 3$ & 0,51 & 0.47 & 1.16 & 0.21 & 0.54 \\
\hline $22: 6$ n3 & 1.22 & 0.88 & 0.05 & 0.03 & 0.45 \\
\hline n3 PUFA & 8.19 & 3.07 & 4.49 & 0.58 & 2.3 \\
\hline Total PUFA & 32.99 & 24.08 & 39.09 & 4.77 & 19.1 \\
\hline n6/n3 & 3.02 & 6.97 & 8.10 & 8.86 & 7.67 \\
\hline
\end{tabular}

SFA - saturated fatty acids. MUFA - monounsaturated fatty acids. PUFA - polyunsaturated fatty acids. n6/n3 - PUFA omega 6 to PUFA omega 3 ratio. ${ }^{1}$ Hoffman et al. (17), ${ }^{2.5}$ Naveena et al. (32), ${ }^{3}$ Filgueras et al. (11), ${ }^{4}$ Turner et al. $(59)$ 
According to the World Health Organisation 600700 million people worldwide are suffering now from iron deficiencies. Haeme iron in meat is more biologically available than the iron from plants, ranging from $72 \%$ to $87 \%$ in red meats (25). Thus, ratite meat seems to be a very good nutritional source of total Fe and haeme $\mathrm{Fe}$ (27). As mentioned above, ratite meat can also be a good source of copper and selenium in comparison to the conventional meat, e.g. beef or chicken meat (Table 4). The comparison between the ratites shows that the ostrich $(0.26 \mathrm{mg} / 100 \mathrm{~g})$ and emu $(0.23 \mathrm{mg} / 100 \mathrm{~g})$ have a higher level of $\mathrm{Cu}$ versus rhea meat $(0.14 \mathrm{mg} / 100 \mathrm{~g})$.

As regards selenium, Ramos et al. (45) and Daun and Akesson (9) demonstrated that selenium content in rhea and emu meat was higher as compared to ostrich meat (44) (Table 4). Interestingly, the results of the study by Poławska et al. (44) indicate that organic form of selenium improves the quality of the ostrich meat by decreasing the $n 6 / n 3$ fatty acids ratio and increasing selenium content in muscles. This form of selenium can be recommended as an antioxidant to ostrich diet, because this form protects linoleic acid against oxidation more effectively than arachidonic acid. The relatively high concentration of selenium in ratite meat is important for consumers since this essential trace element is involved in regulating various physiological functions and implicated in a protective action against cancer in human (14). Selenium deficiency is still a global problem in many countries, which drives government to look for strategies to improve human selenium intake. Selenium content in meat is highly correlated with selenium content in soil and grass. This particular point should be considered in future studies of ratite meat quality.

Calcium concentration in ratite meat varies from $7 \mathrm{mg} / 100 \mathrm{~g}$ in ostrich and $5.4 \mathrm{mg} / 100 \mathrm{~g}$ in emu to $1.9 \mathrm{mg} / 100 \mathrm{~g}$ in rhea. Except for ostrich meat, ratites have relatively low level of calcium as compared to beef and chicken meat (Table 4). Adverse tendency was recorded for phosphorous, the second most abundant mineral in meats. Among ratite birds the highest concentration of the element was found in rhea meat $(384 \mathrm{mg} / 100 \mathrm{~g})$ and this value was also higher than those reported for beef and chicken meat (Table 4). In turn, magnesium content was almost twice higher in ostrich $(28.8 \mathrm{mg} / 100 \mathrm{~g})$ and emu $(25 \mathrm{mg} / 100 \mathrm{~g})$ than in rhea $(15 \mathrm{mg} / 100 \mathrm{~g})$.

Among ratite species, ostrich meat is characterised by low concentration of sodium (43 mg/100 g) as compared to rhea $(64 \mathrm{mg} / 100 \mathrm{~g})$ and emu $(92 \mathrm{mg} / 100 \mathrm{~g})$, making this meat particularly appropriate in hypertension diets. Reduced sodium intake has recently been recommended to limit arterial hypertension, especially in sodium sensitive individuals (8). The zinc content was the highest in emu meat $(3.4 \mathrm{mg} / 100 \mathrm{~g})$ and was twice higher as compared to rhea and chicken meat, but lower than in beef (Table 4).

As regards the vitamin composition in ratite meat, complete scientific data and up-to-date publications are still lacking, especially with reference to emu, rhea and ostrich. The limited data concerning the vitamin content and composition in ratite meat have only been presented in a few incomplete reports and need to be confirmed through more informative studies. Based on the data available in the world literature one can say that ratite meat (especially emu) is also rich in B group vitamins as compared to beef and chicken meat (Table 4). In emu meat the highest level of riboflavin $\left(\mathrm{B}_{2}\right)$ and pyridoxine $\left(\mathrm{B}_{6}\right)$ was found, whereas ostrich meat was the richest in vitamin $B_{12}$. The level of vitamin $\mathrm{E}$ was generally the same in ratites as in beef and chicken meat (Table 4). Interesting data about biologically active peptides like creatine and anserine provided by Pegg et al. (36) also deserve to be mentioned. For example, creatine level in fresh ground emu meat $(0.7 \mathrm{~g} / 100 \mathrm{~g})$ was lower than in beef $(0.78 \mathrm{~g} / 100 \mathrm{~g})$; however, after thermal processing higher levels were detected in emu dried meat $(1.55 \mathrm{~g} / 100 \mathrm{~g})$ than in dried beef $(1.51 \mathrm{~g} / 100 \mathrm{~g})$.

Table 4. Mineral and vitamin contents in ostrich, emu, and rhea meats

\begin{tabular}{|c|c|c|c|c|c|}
\hline & Ostrich $^{1}$ & $E^{2} u^{2}$ & Rhea $^{3}$ & Beef $^{4}$ & Chicken $^{4}$ \\
\hline \multicolumn{6}{|c|}{ Minerals (mg/100 g) } \\
\hline $\mathrm{Ca}$ & 7.04 & 5.3 & 1.89 & $8-11$ & 11 \\
\hline $\mathrm{K}$ & 267 & 317 & 257 & 358 & 229 \\
\hline $\mathrm{Mg}$ & 28.8 & 25.0 & 15.0 & 18.2 & 22.2 \\
\hline $\mathrm{Na}$ & 43.5 & 92 & 64 & $65-89$ & $64-83$ \\
\hline $\mathrm{P}$ & 213 & 230 & 384 & $150-171$ & 173 \\
\hline $\mathrm{Fe}$ & 4.04 & 5.0 & 3.20 & $1.7-2$ & $0.4-0.6$ \\
\hline $\mathrm{Cu}$ & 0.26 & 0.23 & 0.14 & 0.01 & 0.05 \\
\hline $\mathrm{Zn}$ & 2.30 & 3.41 & 1.46 & 4.3 & 1.5 \\
\hline $\mathrm{Se}$ & 0.04 & 0.11 & 0.08 & 0.02 & 0.01 \\
\hline \multicolumn{6}{|l|}{ Vitamins } \\
\hline $\mathrm{B}_{1}(\mathrm{mg} / 100 \mathrm{~g})$ & $0.22^{5}$ & $0.27^{6}$ & - & 0.18 & 0.14 \\
\hline $\mathrm{B}_{2}(\mathrm{mg} / 100 \mathrm{~g})$ & $0.1^{5}$ & $0.46^{6}$ & - & 0.08 & 0.06 \\
\hline $\mathrm{B}_{6}(\mathrm{mg} / 100 \mathrm{~g})$ & $0.23^{5}$ & $0.64^{6}$ & - & 0.12 & 1.5 \\
\hline$B_{12}(\mu g / 100 g)$ & $12.5^{5}$ & $6.75^{6}$ & - & 2.5 & $<1$ \\
\hline $\mathrm{E}(\mathrm{mg} / 100 \mathrm{~g})$ & $0.9^{5}$ & $0.3-0.7^{6}$ & $0.3-0.7^{7}$ & 0.6 & 0.7 \\
\hline
\end{tabular}

${ }^{1}$ Poławska et al. (44), ${ }^{2}$ Naveena (33), ${ }^{3}$ Ramos et al. (45), ${ }^{4}$ Lorenzo et al. (26), ${ }^{5}$ Karklina and Kivite (20), ${ }^{6}$ USDA (60), ${ }^{7}$ Filgueras et al. (11) 
This data shows that processed emu meat snack may be potentially considered as a functional food for athletes keen on performance enhancement through increased consumption of high-quality creatine from a natural food source (36). Moreover, ostrich meat is very rich in anserine as compared to other meats, especially beef. Anserine as a biological dipeptide is present in high concentration in human brain and muscles and plays an important role in protection of the nervous system and skeletal muscles showing high antioxidant activity. Carnosine and anserine are expected to have future therapeutic potential in neurodegenerative diseases (29).

\section{Conclusion}

Ratite meat is a valuable food source. Among red types ratite meat can be considered as dietetic mainly because of low level of fat, high content of PUFA, favourable n6/n3 ratio, and iron content in significantly higher amounts in comparison with beef and chicken meat. This meat will appeal to consumers who are increasingly paying attention to the quality of products they consume.

Regular consumption of ratite meat could provide consumers with various types of bioactive components since ratite meat is rich in selenium, copper, vitamin B, and biologically active peptides like creatine (emu) and anserine (ostrich), and is low in sodium (ostrich). Although ratite meat is abundant in dietetic properties, further study concerning the complete vitamin profile and enrichment of meat with bioactive compounds in order to obtain a product considered as functional is absolutely needed. Moreover, study on technological aspects of ratite meat covering carcass yield improvement, cooking and drip loss, and microbiological aspects of this meat also during storage is necessary.

In turn, the abundance of bioactive compounds, e.g. polyunsaturated fatty acids, makes ratite meat highly susceptible to oxidation (10) and requires research concerning elaboration of innovative intelligent type of packaging in order to protect nutritional and technological properties of the meat so as to ensure better distribution and promotion of ostrich, emu, and rhea meats on the world market. Researchers and industry also have to spend more efforts in educating consumers about the health benefits of ratite meat based on reliable scientific data.

Conflict of Interests Statement: The authors declare that there is no conflict of interests regarding the publication of the article

Financial Disclosure Statement: This investigation was financed by the University of Life Sciences in Warsaw, Faculty of Human Nutrition and Consumer Sciences.

\section{References}

1. Al-Kalifa H., Al-Nasre A.: Ostrich meat: production, quality parameters, and nutritional comparison to other types of meats. J Appl Poult Res 2014, 23, 784-790.

2. Berge P., Lepetit J., Renerre M., Touraille C.: Meat quality traits in the emu (Dromaius novaehollandiae) as affected by muscle type and animal age. Meat Sci 1997, 45, 209-221.

3. Chang Y.S., Hsu D.H., Stromer M., Chou R.G.R.: Postmortem calpain changes in ostrich skeletal muscle. Meat Sci 2016, 117, $117-121$.

4. Charuta A., Tatara M., Krupski W., Poławska E., Ogłuszka M., Pierzchała M., Łuszczewska-Sierakowska I.: Bone morphometric, densitometric and mechanical properties in 14month-old ostriches fed experimental diet enriched with linseed. Anim Sci Pap Rep 2015, 33, 383-398.

5. Cooper R.G., Naranowicz H., Maliszewska E., Tennett A., Horbańczuk J.O.: Sex-based comparison of limb segmentation in ostriches aged 14 months with and without tibiotarsal rotation. J S Afr Vet Assoc 2008, 79, 142-144.

6. Cooper R.G., Tomasik C., Horbańczuk J.O.: Avian influenza in ostriches (Struthio camelus). Avian Poult Biol Rev 2007, 18, 87-92.

7. Dalle Zotte A., Brand T.S., Hoffman L.C., Schoon K., Cullere M., Swart R.: Effect of cottonseed oilcake inclusion on ostrich growth performance and meat chemical composition. Meat Sci 2013, 93, 194-200.

8. Dalle Zotte A., Szendro Z.: The role of rabbit meat as functional food. Meat Sci 2011, 88, 319-331.

9. Daun C., Akesson B.: Comparison of glutathione peroxidase activity, and of total and soluble selenium content in two muscles from chicken, turkey, duck, ostrich and lamb. Food Chem 2004, $85,295-303$

10. Filgueras R.S., Astruc T., Labas R., Venien A., Peyrin F., Zamiazi R.C., Sante-Lhoutellier V.: Relationship between histochemical, structural characteristics and oxidative stability of rhea limb muscles. Food Chem 2012, 132, 1387-1394.

11. Filgueras R.S., Gatellier P., Aubry L., Thomas A., Bauchard D., Durand D., Zambiazi R.C., Sante-Lhoutellier V.: Colour, lipid and protein stability of Rhea americana meat during air- and vacuum-packed storage: influence of muscle on oxidative processes. Meat Sci 2010, 86, 665-673.

12. Filgueras R.S., Gatellier P., Ferreira C., Zambiazi R.C., Sante-Lhoutellier V.: Nutritional value and digestion rate of rhea meat proteins in association with storage and cooking processes. Meat Sci 2011, 89, 6-12.

13. Filgueras R.S., Gatellier P., Zambiazi R.C., Sante-Lhoutellier V.: Effect of frozen storage duration and cooking on physical and oxidative changes in $m$. gastrocnemius pars interna and $m$. iliofiburalis of Rhea americana. Meat Sci 2011, 88, 645-651.

14. Gramadzinska J., Reszka E., Bruzelius K., Wasowicz W., Akesson B.: Selenium and cancer: biomarkers of selenium status and molecular action of selenium supplements. Eur J Nutr 2008, $47,29-50$.

15. Hoffman L.C., Botha S.S.C., Britz T.J.: Muscle $\mathrm{pH}$ and temperature changes in hot- and cold-deboned ostrich (Struthio camelus var. domesticus) muscularis gastrocnemius, pars interna and muscularis iliofibularis during the first $23 \mathrm{~h}$ postmortem. Meat Sci 2007, 75, 343-349.

16. Hoffman L.C., Jones M., Muller M., Joubert E., Sadie A.: Lipid and protein stability and sensory evaluation of ostrich (Struthio camelus) droëwors with the addition of rooibos tea extract (Aspapathus linearis) as a natural antioxidant. Meat Sci 2014, 96, 1289-1296.

17. Hoffman L.C., Joubert M., Brand T.S., Manley M.: The effect of dietary fish oil rich in $n-3$ fatty acids on the organoleptic. fatty acid and physicochemical characteristics of ostrich meat. Meat Sci 2005, 70, 45-53.

18. Hoffman L.C., Muller M., Cloete S.W.P., Brand M.: Physical and sensory meat quality of South African Black ostriches 
(Struthio camelus var. domesticus). Zimbabwean Blue ostriches (Struthio camelus australis) and their hybrid. Meat Sci 2008, 79, 365-374.

19. Jeengar M.K., Kumar P.S., Thummuri D., Shrivastava S., Guntuku L., Sistla R., Naidu V.G.M.: Review on emu products for use as complementary and alternative medicine. Nutrition 2015, 31, 21-27.

20. Karklina D., Kivite J.: The nutritional value of ostrich meat produced in Latvia. Proceedings of the XIV World Ostrich Congress. Riga, Latvia. 2007, pp. 83-85.

21. Kawka M., Horbańczuk J.O., Sacharczuk M., Zięba G., Łukaszewicz M., Jaszczak K., Parada R.: Genetic characteristics of the ostrich population using molecular methods. Poult Sci 2007, 86 277-281.

22. Kawka M., Parada R., Jaszczak K., Horbańczuk J.O.: The use of microsatellite polymorphism in genetic mapping of the ostrich (Struthio camelus). Mol Biol Rep 2012, 39, 3369-3374.

23. Kawka M., Horbańczuk J.O., Jaszczak K., Pierzchała M., Cooper R.G.: A search for genetic markers associated with egg production in the ostrich (Struthio camelus). Mol Biol Rep 2012, 39, 7881-7885.

24. Leygonie C., Britz T.J., Hoffman L.C.: Meat quality comparison between fresh and frozen/thawed ostrich $m$. iliofibularis. Meat Sci 2012, 91, 364-368.

25. Lombardi-Boccia G., Martinez-Dominguez B., Aguzzi A., Rincon-Leon F.: Optimization of heme iron analysis in raw and cooked red meat. Food Chem 2002, 78, 505-510.

26. Lorenzo J.M., Sarries M.V., Tadeo A., Polidori P., Franco D., Lanza M.: Carcass characteristics, meat quality and nutritional value of horsemeat: a review. Meat Sci 2014, 96, 1478-1488.

27. Majewska D., Jakubowska M., Ligocki M., Tarasewicz Z., Szczerbińska D., Karamucki T., Sales J.: Physiochemical characteristics, proximate analysis and mineral composition of ostrich meat as influence by muscle. Food Chem 2009, 117, 207-211

28. Menon D.G., Bennett D.C., Uttaro B., Schaefer A.L., Cheng K.M.: Carcass yield and meat quality characteristics of adult emus (Dromaius novaehollandiae) transported for $6 \mathrm{~h}$ before slaughter. Meat Sci 2014, 98, 240-246.

29. Mizuno D., Konoha-Mizuno K., Mori M., Sadakane Y., Koyama H., Ohkawara S., Kawahara M.: Protective activity of carnosine and anserine against zinc-induced neurotoxicity: a possible treatment for vascular dementia. Metallomics 2015, 8, 1233-1239.

30. Morris C.A., Harris S.D., May S.G., Jackson D.S., Hale S.D., Miller R.K., Keeton J.T., Acuff G.R., Lucia L.M., Savell J.W.: Ostrich slaughter and fabrication. 1. Slaughter yields of carcasses and effects of electrical stimulation on post mortem $\mathrm{pH}$. Poult Sci 1995, 74, 1683-1687.

31. Nair M.N., Suman S.P., Li S., Joseph P., Beach C.M.: Lipid oxidation-induced oxidation in emu and ostrich myoglobins. Meat Sci 2014, 96, 984-993.

32. Naveena B.M., Kiran M.: Emu meat: new source of healthier meat towards niche market. Food Rev Int 2014, 30, 22-35.

33. Naveena B.M., Muthukumar P.S., Kulkarni V.V., Praveen Kumar Y. Usha Rani K., Kiran M.: Effect of aging on the physicochemical, textural, microbial and proteome changes in emu (Dromaius novaehollandiae) meat under different packaging conditions. J Food Process Pres 2015, 39, 2497-2506.

34. Naveena B.M., Sen A.R., Muthukumar P.S., Girish P.S., Praveen Kumar Y. Kiran M.: Carcass characteristics. Composition, physico-chemical, microbial and sensory quality of emu meat. Brit Poult Sci 2013, 54, 329-336.

35. Paleari M.A., Camisasca S., Beretta G., Renon G., Corsico P., Bertolo G., Crivelli G.: Ostrich meat: physico-chemical characteristics and comparison with turkey and bovine meat. Meat Sci 1998, 48, 205-210.

36. Pegg R.B., Amarowicz R., Code W.E.: Nutritional characteristics of emu (Dromaius novaehollandiae) meat and its value-added products. Food Chem 2006, 97, 193-202.
37. Poławska E., Marchewka J., Cooper R.G., Sartowska K., Pomianowski J., Jóźwik A., Strzałkowska N., Horbańczuk J.O.: The ostrich meat - an updated review. II. Nutritive value. Anim Sci Pap Rep 2011, 29, 89-97.

38. Poławska E., Marchewka J., Krzyżewski J., Bagnicka E., Wójcik A.: The ostrich meat - an updated review. I. Physical characteristics of ostrich meat. Anim Sci Pap Rep 2011, 29, 5-18.

39. Poławska E., Lisiak D., Jóźwik A., Pierzchała M., Strzałkowska N., Pomianowski J., Wójcik A.: The effect of the diet supplementation with linseed and rapeseed on the physicochemical and sensory characteristics of ostrich meat. Anim Sci Pap Rep 2012, 30, 65-72.

40. Poławska E., Cooper R.G., Jóźwik A., Pomianowski J.: Meat from alternative species - nutritive \& dietetic value and its benefit for human health - A review. CyTa J Food 2013, 11, $37-42$.

41. Poławska E., Horbańczuk J.O., Pierzchała M., Strzałkowska N., Jóźwik A., Wójcik A., Pomianowski J., Gutkowska K., Wierzbicka A., Hoffman L.C.: Effect of dietary linseed and rapeseed supplementation on the fatty acid profiles in the ostrich. Part 1. Muscles. Anim Sci Pap Rep 2013, 31, 239-248.

42. Poławska E., Póltorak A., Wyrwisz J., Wierzbicka A., Gutkowska K., Pomianowski J., Zdanowska-Sąsiadek Ż., Wójcik A., Kawka M., Raes K., De Smet S.: The physical traits and fatty acids profile of ostrich meat enriched in N3 fatty acids as influenced by duration of refrigerated storage and type of packaging. Anim Sci Pap Rep 2014, 32, 351-358.

43. Poławska E., Tolik D., Horbańczuk O.K., Ciepłoch A., Raes K., De Smet S.: The effect of dietary oil seeds on the fatty acid profile and metabolism in ostrich liver. Anim Sci Pap Rep 2016, 34, 173-180.

44. Poławska E., Zdanowska-Sąsiadek Ż., Horbańczuk J.O., Pomianowski J., Jóźwik A., Tolik D., Ras K., De Smet S.: Effect of dietary organic and inorganic selenium supplementation on chemical, mineral and fatty acid composition of ostrich meat. CyTa J Food 2016, 14, 84-87.

45. Ramos A., Cabrera M.C., Del Puerto M., Saadoun A.: Minerals. Haem and non-haem iron contents of rhea meat. Meat Sci 2009, $81,116-119$

46. Romanelli P.F., Trabuco E., Scriboni A.B., Visentainer J.V., De Souza N.E.: Chemical composition and fatty acid profile of rhea (Rhea americana) meat. Arch Latinoam De Nutr 2008, 58, 201-205.

47. Sales J.: The rhea. A ratite native to South Africa. Avian Poult Biol Rev 2006, 17, 105-124.

48. Sales J.: The emu (Dromaius novaehollandiae): A review of its biology and commercial products. Avian Poult Biol Rev 2007, $18,1-20$.

49. Sales J., Horbańczuk J.O., Dingle J., Coleman R., Sensik S.: Carcase characteristics of emus (Dromaius novaehollandiae). Brit Poult Sci 1999, 40, 145-147.

50. Sales J., Navarro J.L., Bellis L., Manero A., Lizurume M., Martella M.B.: Carcase and component yields of rheas. Brit Poult Sci 1997, 38, 378-380.

51. Sales J., Navarro J.L., Bellis L., Manero A., Lizurume M., Martella M.B.: Post mortem $\mathrm{pH}$ decline as influenced by species in different rhea muscles. Vet J 1998, 155, 209-211.

52. Sales J., Navarro J.L., Martella M.B., Lizurume M.E., Manero A., Bellis L., Garcia P.T.: Cholesterol content and fatty acid composition of rhea meat. Meat Sci 1999, 53, 73-75.

53. Simopoulos A.P.: Evolutionary aspects of diet. The omega6/omega-3 ratio and genetic variation: nutritional implications for chronic diseases. Biomed Pharmacother 2006, 60, 502-507.

54. Simopoulos A.P.: The importance of the omega-6/omega-3 fatty acid ratio in cardiovascular disease and other chronic diseases. Exp Biol Med 2008, 233, 6, 674-688.

55. Suman S.P., Joseph P., Li S., Beach C.M., Fontaine M., Steinke L.: Amino acid sequence of myoglobin from emu (Dromaius novaehollandiae) skeletal muscle. Meat Sci 2010, 86, $623-628$. 
56. Terevinto A., Ramos A., Castroman G., Cabrera M.C., Saadoun A.: Oxidative status in vitro iron-induced lipid oxidation and superoxide dismutase. Catalase and glutathione peroxidase activities in rhea meat. Meat Sci 2010, 84, 706-710.

57. Walter J.M., Soliah L., Dorsett D.: Ground ostrich: a comparison with ground beef. J Am Diet Assoc 2000, 100, 244-245.

58. World Health Organization/Food and Agriculture Organization (WHO/FAO), - Diet nutrition and the prevention of chronic diseases. WHO, Geneve, 2003, pp. 4-101.
59. Turner T.D., Jensen J., Pilfold L., Prema D., Donkor K.K., Cinel B., Thompson J., Dugan M.E.R., Church J.S.: Comparison of fatty acids in beef tissues from conventional organic and natural feeding systems in Western Canada. Can J Anim Sci 2015, 95, 49-58

60. USDA National Nutrient Database for Standard Reference 2016. Basic Report 05621. Emu. Ground. raw. May 2016. 